\title{
Understanding Sharia in the West
}

\author{
Maurits S. Berger \\ Maurits S. Berger (LLM, PhD) is a full professor of Islam and the West \\ at Leiden University \\ m.s.berger@hum.leidenuniv.nl
}

\begin{abstract}
The main challenge of understanding Sharia in the West is its undefined nature. This contradicts the ease with which the term is used in public and political discourse, but also in the legal domain, which prides itself on its precision in terminology. This article addresses the question: What is the Sharia that Muslims in the West practice? To this end, a model is presented that provides tools to describe the complex interaction between Sharia, as practiced by Western Muslims, and their Western environment, and elucidates the ongoing dialectic of this interaction. The model further shows how Western Muslims adopt and adapt Sharia by manoeuvring between their specific needs in the Western context and the conditions set by that context. From a Western perspective, the model shows that issues of Sharia are usually discussed in legal terms, while most controversies are not legal but cultural in nature.
\end{abstract}

\section{Keywords}

Sharia in the West - Islamic law - religious law - law and religion - comparative law legal pluralism - legal culture - freedom of religion

\section{Introduction}

In this article, I propose a conceptual legal-anthropological approach to the notion of "Sharia in the West." Although the term "Sharia" is widely used in the West, it is rife with contradiction and confusion. For example, in 2003, the European Court of Human Rights ruled that "Sharia clearly diverges from 
[the European] Convention [on Human Rights] values."1 The case regarded the Turkish state, which had banned the Islamic Refah Party for proclaiming its intention to implement Sharia. The ruling is understandable, given the fact that members of the Refah Party were issuing threatening remarks when calling for Sharia. ${ }^{2}$ From a legal point of view, however, the ruling is surprising because the Court failed to define what it meant by "Sharia." If a legal body like the Court uses notions that are alien to the legal language of that body, one would expect some clarification. But none was given. This makes the ruling nebulous, given the fact that Sharia also includes rules pertaining to prayer, fasting, and burial. Surely, the Court can hardly consider these contrary to European human rights values.

Five years later, on separate occasions in 2008, the Archbishop of Canterbury and the Lord Chief Justice of England and Wales came to an opposite conclusion from that of the European Court: in public speeches they suggested that Sharia does not necessarily have to be contradictory to Western legal and political values. ${ }^{3}$ These remarks were met with scorn and outrage. ${ }^{4}$ But, just as in the case of the European Court, both the highest judicial and religious authority of England failed to clearly define what they meant by "Sharia."

The contradictory use of the notion of Sharia in a Western context illustrates the ongoing confusion about the meaning of this term. This is understandable, given the widely divergent Sharia practices we witness nowadays, ranging from violent and oppressive practices by ISIS or Taliban to the tolerance and

1 ECHR, Refah vs. Turkey, 13 February 2003, Nos. 41340/98, 41342/98, 41343/98 and 41344/98. For commentaries, see Kevin Boyle, "Human Rights, Religion and Democracy: The Refah Party Case", 1 Essex Human Rights Review (2004), 1; David Schilling, "European Islamaphobia and Turkey - Refah Partisi (The Welfare Party) v. Turkey”, 26 Loyola Los Angeles Law Rev of Int and Comp Law (2004), 501.

2 These remarks included: "We shall certainly call to account those who turn their backs on the precepts of the Koran and those who deprive Allah's Messenger of his jurisdiction in their country;" "This system must change. We have waited, we will wait a little longer. Let us see what the future has in store for us. And let Muslims keep alive the resentment, rancour and hatred they feel in their hearts;" "If anyone attacks me I will strike back. I will fight to the end to introduce Sharia." (ECHR, ibid).

3 Rowan Williams, "Civil and Religious Law in England: a religious perspective", 10 Ecclesiastical Law Journal (2008), 262; Lord Phillips, Equality before the Law: Speech by Lord Phillips, Lord Chief Justice (London Muslim Centre, 2008).

4 See the commentaries in Rex Ahdar and Nicholas Aroney (eds.) Shari'a in the West (Oxford Univ. Press, 2010). 
generosity practiced by many other Muslims. We find similar contradictions in the centuries-old classical legal scholarship that is also called Sharia, and that has produced a vast volume of literature with a multitude of interpretations. Given these conflicting manifestations of Sharia, it is striking that in public, legal, and political discourse, both Muslims and non-Muslims see so little need in explaining the term, but keep referring to it with self-evident assurance.

By contrast, in academic circles one finds more nuanced definitions of Sharia. But whereas the notion of "Sharia in the West" is gradually becoming a field of research in its own right, comprehensive characterizations of what this notion entails are absent. This has to do with the different disciplinary and geographic approaches that are applied to the subject. For instance, Sharia in the West is often studied from the point of view of the effects that contemporary practices and laws of Muslim majority countries may have in Western societies, some scholars focusing on the practices in these countries, ${ }^{5}$ others studying the ways in which these foreign Sharia laws are applied in Western courts through international private law. ${ }^{6}$ This approach has its relevance, but it fails to address the domestic and autonomous practices of Sharia by Muslims in the West. Research on this topic is gradually emerging, but is still scant and dispersed over various domains of interest. The domain that receives the most academic attention is Islamic family law, either as it is practiced by Muslims (this domain is still little researched), ${ }^{7}$ or as it is manifest in the so-called

5 See, e.g., Jorgen S. Nielsen and Lisbet Christoffersen (eds.) Sharia As Discourse. Legal Traditions and the Encounter with Europe (Routledge, 2010).

6 See, e.g., Andrea Büchler, Islamic Law in Europe? Legal Pluralism and its Limits in European Family Laws (Routledge, 2011); Pauline M. Kruiniger, Islamic divorces in Europe. Bridging the gap between European and Islamic legal orders (2014); Julie Macfarlane, Islamic Divorce in North America: A Sharia Path in a Secular Society (Oxford Univ. Press, 2012); Asifa Quraishi and Najeeba Syeed-Miller, "No Altars: A Survey of Islamic Family Law in the United States" in Lynn Welchman (ed.), Women's Rights \& Islamic Family Law (2004), 179; Iris D.A. Sportel, "Maybe I'm still his wife". Transnational divorce in Dutch-Moroccan and Dutch-Egyptian families (Radboud Univ. Nijmegen, 2014); Emily L. Thompson and Soniya F. Yunus, "Choice of Laws or Choice of Culture: How Western Nations Treat the Islamic Marriage Contract in Domestic Courts", 25 Wisconsin International Law Journal (2007), 361.

7 See, e.g., Lucy Carrol, "Application of the law. Muslim women and 'Islamic divorce' in England", 17 Journal of Muslim Minority Affairs (1997), 97; Annelies Moors, "Unregistered Islamic Marriages: Anxieties about Sexuality and Islam in the Netherlands", in Maurits S. Berger (ed.), Applying Sharia in the West. Facts, Fears and the Future of Rules of Islam on Family Relations in the West (2013), 141; Emmanuelle Santelli and Beate Collet, "Le mariage 'halal': Réinterprétation des rites du mariage musulman dans le contexte postmigratoire français", Recherches familiales (2012), 83; Gaby Starssburger, "Auf die Liebe kommt es an! - Beziehungsideale und - entscheidungen junger Muslime", in Hans-Jürgen 
Muslim arbitration tribunals. ${ }^{8}$ Another domain of academic interest is the Western case law regarding the freedom of religion. ${ }^{9} \mathrm{~A}$ third field of research that receives substantial attention is the increasing body of fatwas issued for the benefit of Muslims in the West, and in particular the development of the so-called "Fiqh for minorities" (figh al-aqalliyat). ${ }^{10}$ Our current understanding

von Wensierski and Claudia Lübcke (eds.), Junge Muslime in Deutschland: Lebenslagen, Aufwachsprozesse und Jugendkulturen (Barbara Budrich, 2007), 195; Ihsan Yilmaz, "The challenge of post-modern legality and Muslim legal pluralism in England", 28 Journal of Ethnic and Migration Studies (2002), 343.

8 For the UK, see, e.g., Samia Bano, Islamic Dispute Resolution and Family Law (2011); Jessie Brechin, "A Study of the Use of Sharia Law in Religious Arbitration in the United Kingdom and the Concerns that this Raises for Human Rights", 15 Ecclesiastical Law Journal (2013), 293; Ayelet Shachar, Multicultural Jurisdictions: cultural differences and women's rights (Cambridge Univ. Press, 2011); Sonia N. Shah-Kazemi, Untying the Knot: Muslim Women, Divorce and the Shariah (Nuttfield Foundation, 2001); Jemma Wilson, "The Sharia Debate in Britain: Sharia Councils and the Oppression of Muslim Women”, 1 Aberdeen Student Law Review (2010), 46. For Canada, see, e.g., Natasha Bakht, "Family Arbitration Using Sharia Law: Examining Ontario's Arbitration Act and its Impact on Women", Muslim World Journal of Human Rights (2004), 1; Lynne Cohen, "Inside the Beit Din", 5 Canadian Lawyer (2000), 27. For the Netherlands, see, e.g., Laurens G.H. Bakker et al., Sharia in Nederland. Een studie naar islamitische advisering en geschilbeslechting bij moslims in Nederland (2010); Maurits S. Berger, "De (on)mogelijkheid van Sharia in Nederland. Met voorstellen voor toepassing van islamitisch familierecht", in Katharina Boele-Woelki (eds.), Actuele ontwikkelingen in het familierecht (Ars Aequi, 2015), 69. For a general discussion, see Mathias Rohe, "Alternative Dispute Resolution in Europe under the Auspices of Religious Norms", 6 RELIGARE Working Paper (2011). <http://www.religareproject.eu/system/ files/Alternative\%2oDispute\%2oResolution\%2oby\%2oRohe\%2oe-version.pdf $>$.

Carolyn Evans, "The 'Islamic Scarf' in the European Court of Human Rights", 7 Melbourne Journal of International Law (2006), 52; Dominic McGoldrick "Accommodating Muslims in Europe: From Adopting Shari'a Law to Religiously Based Opt Outs from Generally Applicable Laws", 9 Human Rights Law Review (2009), 6o3; Robin Griffith-Jones (ed.), Islam and English Law: Rights, Responsibilities and the Place of Sharia (2013); Mathias Rohe, Muslim Minorities and the Law in Europe: Chances and Challenges (2007).

See, e.g., Țaha J. Alwani, Towards a figh for Minorities (International Institute for Islamic Thought, 200o); Alexandre Caeiro, Fatwas for European Muslims: The Minority Fiqh Project and the Integration of Islam in Europe (2011); Dilwar Hussain, "Muslim Political Participation in Britain and the 'Europeanisation' of Fiqh", 3 Die Welt des Islams (2004), 376; Shammai Fishman, Figh al-Aqalliyyat: A Legal Theory for Muslim Minorities (Center on Islam, Democracy, and the Future of the Muslim World, 2006); Tareq Oubrou, Introduction théorique à la charî́a de Minorité (Oumma, 2000). <http://oumma.com/Introduction -theorique-a-la-chari>; Youssef Qaradawi, Fiqh of Muslim Minorities (New Vision, n.d.); Said F. Hassan, "Fiqh al-Aqalliyyāt: Negotiating Discourse of Tradition, Modernity and Reform”, 5 Faculty of Languages and Translation's Journal (2013), 219. 
of Sharia in the West is therefore fragmented qualitatively (the interpretations and manifestations of Sharia) and almost absent quantitatively (the practices of Sharia, and the number of Muslims adhering to them).

The different approaches to Sharia in the West and its manifestations warrant a comprehensive consideration. To do so, I expound a legal-anthropological model that can be used to reach an integrated understanding of this complex notion. The two basic questions I address when speaking of Sharia in the West are "What are we talking about?" and "What should we be talking about?" Sharia in the West, which has become a standard expression in practice as well as in academia, will serve as our central point of reference. The construction of this model therefore, involves the reconsideration of several basic notions: What is law? What makes a rule Islamic? What do we mean by "the West" and Western values? We must also take into account the interaction between Sharia and the Western legal and societal structures in which it is embedded. This dimension is crucial to our understanding of Sharia in the West, because there is a continuous dialectic going on between the different ways in which Sharia is practiced and interpreted by Muslims in the West, and the various Western responses to these practices and interpretations. ${ }^{11}$

Below I present the step-by-step construction of this model of Sharia in the West, in three parts. In the first part I address the notion of Sharia, with emphasis on what Muslims in Western societies do and want with respect to Sharia. I review the manners in which Sharia is being applied by Western Muslims, and the domains in which they do so, which in many instances are particular to a Western context. In the second part I discuss the Western environment in which this Sharia operates, and the Western responses to Sharia. Analysis of these responses shows that they can be divided into two categories, politicallegal and religious-cultural. In the third part I demonstrate that Sharia in the West is not a mere injection of a fossilized and alien legal system into Western societies, but the result of a dialectic between the two, which is still in a process of development.

11 This dialectic has been an important part of my research; see, e.g., "The Third Wave: Islamization of Europe, or Europanization of Islam?", 2 Journal of Muslims in Europe (2013), 115-136; "Introduction: Applying Shari'a in the West", in Maurits S. Berger (ed.), Applying Sharia in the West (2013), 7-22; "Responding to Sharia in the Netherlands", (33-34) Canadian Journal of Netherlandic Studies / Revue Canadienne des études Néerlandaises (2014), 129-152; Maurits S. Berger, A Brief History of Islam in Europe. Thirteen Centuries of Creed, Conflict and Coexistence (Leiden Univ. Press (2014), in particular the last two chapters). 


\section{Part I Sharia}

\section{1 \\ Representations of Sharia}

The main challenge in understanding what Sharia entails is that it is not a singular notion, nor a code of law contained in a corpus of legal rules. In the modern Muslim world, it survives in three forms: as scholarship, as a set of rules inserted into the modern legal system, and as a slogan. I briefly consider each of these representations to explain their relevance to our discussion of Sharia in the West.

\subsection{Classical Legal Scholarship}

Islamic classical legal scholarship, that is, the scholarship developed in the early centuries of Islam and which is part of Islamic orthodoxy, is not preoccupied with the production of rules, as is the case, for instance, in canon law, but with the science of finding and interpreting rules. ${ }^{12}$ Over the centuries, this scholarship has yielded a massive volume of literature comprising a host of rules and interpretations. The fact that many of these interpretations differ from one another is not considered problematic from the Islamic scholarly point of view, because the essence of this scholarship is that one makes a serious intellectual effort (ijtihad) to come to a solution, thereby allowing for different scholars to have different opinions.

Islamic legal scholarship defined two areas in which human relations are expressed: one between man and God (ibadat), the other between man and man (mu'amalat). The first category comprises actions like prayer, fasting, and burial, which one would nowadays call religious rituals and which modern legal standards regard as situated outside the realm of law. The relations between men, by contrast, typically pertain to the modern concept of law. Islamic legal scholarship, however, limited itself to only a few fields of law: family law, financial transactions, a small number of crimes, and some general rules on arbitration and government. All other fields of law, therefore, were not subject to scholarly scrutiny, but pertained to the realm of worldly rule (sulta). ${ }^{13}$ The ruler would uphold Sharia on one hand, and promulgate laws according to

12 e.g., Khaled Abou El Fadl, Reasoning with God: Reclaiming Shariah in the Modern Age (2014); Wael B. Hallaq, Shari'a: Theory, Practice, Transformations (2009); Mohammed H. Kamali, Shari'ah Law: An Introduction (2008).

13 Ira M. Lapidus, "The Separation of State and Religion in the Development of Early Islamic Society", 6 International Journal of Middle East Studies (1975), 363; Knut S. Vikør, Between God and the Sultan: A History of Islamic Law (2006) $185 \mathrm{ff}$. 
his own wishes on the other, as long as they were not in violation of the basic tenets of Sharia.

\subsection{Modern Applications}

The second representation of Sharia is its actual practice. In the modern Muslim world, this has taken two forms: either as a code of conduct practiced outside state rule, or as a set of rules of the state legal system. ${ }^{14}$

Sharia as a code of conduct can be practiced or applied outside the sphere of state rule either within a small communal setting, or in the form of a broader enforcement of such codes by militant groups like the Taliban or ISIs. This form of Sharia has many different manifestations, ranging from militant and harsh applications to a wide variety of Islamic charity organizations and sustainable development initiatives in the private domain. ${ }^{15}$

Sharia as legislation is a novelty, dating from the late 19th century, when some domains of Islamic legal scholarship were codified. Because the extensive corpus of Islamic scholarship contained many alternatives and even contradictions, the legislators had to make choices. For example, most Muslim majority countries have codified Islamic family law into a single, national law, but the family laws of, for instance, Iran, Pakistan, Morocco, and Tunisia differ in many respects. ${ }^{16}$ Since the second half of the 2oth century, codification on the basis of Islamic principles has gained popularity in many Muslim countries, but again, within their national contexts. Many typical features of the modern nation state, like a legislature and judiciary, at times combined with a monarchy or a democracy, are maintained within the self-declared Islamic polity, although these institutions have little basis in classical Islamic legal scholarship.

14 Maurits S. Berger, "Sharia and the Nation State", in Rudolph Peters and Peri Bearman (eds.), The Ashgate Research Companion to Islamic Law (2014), 223; Jan M. Otto, Sharia Incorporated. A Comparative Overview of the Legal Systems of Twelve Muslim Countries in Past and Present (2011).

15 The latter is also known as "green Islam," see, e.g., Zeyneb Hafsa Aström, "Paradigm Shift for Sustainable Development: The Contribution of Islamic Economics", 1 Journal of Economic and Social Studies (2011); Mnawar Iqbal (ed.), Islamic Perspectives on Sustainable Development (2005); Zubair Hasan, "Sustainable development from an Islamic Perspective: meaning implications and policy concerns", 19 JKAU: Islamic Economics (2006), 3 .

Berger, supra note 14; Otto, supra note 14. 
The modern interpretations and appearances of Sharia in its social, legal, and constitutional forms are quite unique in the history of Sharia. Although many of these interpretations have become popular in the Muslim world, they are not without criticism. Some critics disagree about the right interpretation of certain rules of Islam, while others argue that modern applications of socalled Sharia are not in conformity with the tenets of Islamic legal scholarship. ${ }^{17}$

\subsection{Slogan}

Finally, and perhaps most important, is the representation of Sharia as what I suggest to call a slogan. ${ }^{18}$ The term "Sharia" has a strong and positive reverberation among devout Muslims, irrespective of what Sharia is or how it is applied. Sharia stands for something "good." In this respect, it can be compared to the term "justice," which also stands for something good, even if there is much controversy regarding its exact meaning and application. This is not to say that Sharia is the equivalent of justice, but the slogan mechanism in both instances is similar. Sharia is extremely powerful in this sense: no devout Muslim would disavow Sharia (as has been suggested by some Western politicians as a condition for Muslim integration); and for many Muslims living in poverty or under oppression, Sharia has become a utopian solution.

\subsection{Sharia as Lived Practice}

These three representations refer to the notion of Sharia in general, with a focus on Muslim majority countries. What representations do we encounter when we shift our focus on the manifestation of Sharia in the West? Studying Sharia as either Islamic scholarship or as practices in individual Muslim countries is of little use in answering this question, because neither manifestation reflects or explains the situation and practice of Sharia in the West. Because there is no written code of Sharia, let alone one of Sharia in the West, nor any other comprehensive recording of Sharia jurisprudence or practices in the West, the only approach that may provide us with sufficient answers is Sharia as a lived practice. To explore this practice, we must zoom in on what Muslims in the West want or mean by Sharia, and what they do in connection with it.

\footnotetext{
17 Khaled Abou El Fadl, Speaking in God's Name. Islamic Law, Authority and Women (2001), 171; Wael A.B. Hallaq “Can the Shari'a be restored?", in Yvonne Y. Haddad and Barbara F. Stowasser (eds.), Islamic Law and the Challenges of Modernity (2004), 22.

18 Maurits S. Berger, "Sharia - A Flexible Notion", 35 Rechtsfilosofie \& Rechtstheorie (2006), 335-345.
} 


\subsection{What Do Muslims in the West Mean by Sharia?}

To my knowledge, only three surveys have been conducted among Muslims in European countries, and two among Muslims worldwide, in which Muslims were asked their opinion about Sharia. In a 2008, a Gallup poll held in ten Muslim majority countries, which claimed a representation of $80 \%$ of Muslims worldwide, Sharia and (to the surprise of many) democracy shared joint first place on the list of what Muslims found important in their lives. ${ }^{19}$ A Pew survey in 2013 yielded a similar result, with the wish to "make Sharia the official law in the country" scoring high, especially in Asian Muslim majority countries. ${ }^{20}$

These two worldwide surveys, however, did not cover Western countries with Muslim minority populations. Only three surveys have covered this ground. One was conducted in 2004 in the Netherlands, and found that $51 \%$ of Dutch Muslims interviewed favoured a Muslim political party, and 29.5\% thought that its political program should be based on Sharia. ${ }^{21}$ The other two surveys were conducted in the UK, in 2006 and 2007. According to the 2006 survey, $40 \%$ of the 500 British Muslim respondents said that they would support the introduction of Sharia in predominantly Muslim areas of Britain, and 91\% of respondents declared themselves "loyal towards Britain." ${ }^{22}$ The 2007 study found that $28 \%$ of British Muslims would prefer to live under Sharia law. ${ }^{23}$

Sharia obviously enjoys a favorable standing among Muslims. But none of these five surveys defined Sharia, nor did they ask their respondents to do so, therefore failing to shed light on what the Muslim respondents meant by Sharia. Does it appeal to them as a slogan for righteousness, as a religious code of conduct, or as a harsh Taliban-like system? The surveys do not make this clear.

19 John L. Esposito and Dalia Mogahed, Who speaks for Islam? What a Billion Muslims Really Think (2008).

20 The Pew Forum, The World's Muslims: Religion, Politics and Society (April 30, 2013<http:// www.pewforum.org/Muslim/the-worlds-muslims-religion-politics-society.aspx >).

To be more exact, $10.2 \%$ of the respondents who favoured a Muslim political party, answered the question "Should the programme of this party be based on Sharia?" with "Yes, entirely" and 19.3\% answered "Yes, to some extent" (Foquz Etnomarketing, "Onderzoeksresultaten 'Politieke Voorkeuren Moslims' t.b.v. Redactie Nova”, Nieuwegein: Foquz Etnomarketing, December 2004, 10-12).

22 ICM Research survey among 500 Muslims, February 2006, <http://www.icmunlimited .com/pdfs/2006_february_sunday_telegraph_muslims_poll.pdf $>$.

23 Munira Mirza et al., Living Apart Together. British Muslims and the Paradox of Multiculturalism (2007). 


\subsection{What Do Muslims in the West Do in Terms of Sharia?}

In the absence of well-founded insight into what Muslims in the West or worldwide mean by Sharia, or what they want with respect to Sharia, our next best option is to come to an understanding of what Muslims in the West do with respect to Sharia. This approach is not entirely satisfactory either, because it overlooks the possibility that some Muslims may wish to practice certain forms of Sharia but are prevented from doing so by their social or legal environment (as for example, wearing the burqa in countries like France and Belgium, gender separation in public places, or applying Islamic corporal punishments). Some Muslims may entertain ideas of a social and legal order, whether communal or national, that are disallowed as a threat to state security. ${ }^{24}$ We must therefore acknowledge that until a thorough survey on this question is conducted we can only speculate about the intentions of Muslims in the West.

Taking into consideration this lacuna in our approach, I limit our model to that of the Sharia expressed or practiced by Muslims in the West. To this end, it is useful to consider three legal domains where we observe Sharia being practiced in the West: national law, foreign law through international private law, and informal legal practices. ${ }^{25}$

\subsubsection{National Law}

Few rules of Islamic law are part of a Western national law. One example is that of the so-called Sharia courts, which exist in the Greek province of Western Thrace, headed by muftis. These courts pronounce marriages and divorces as a matter of state law. ${ }^{26}$ By contrast, the Sharia councils in the UK are not state recognized. Another example is national laws that make specific allowances for Islamic religious rituals, such as burial rites, ritual slaughter, and dietary requirements in government facilities. In the $\mathrm{UK}$, special provisions were made by law in 2003 to accommodate Islamic financial instruments. Furthermore,

24 Although most security services focus on acts of violence as a threat to national security, some, like the Dutch security service (AIVD), also consider certain lifestyles in secluded communities ("parallel societies") as a potential source of radicalization, and therefore a threat to national security (AIVD, The radical dawa in transition, The rise of Islamic neoradicalism in the Netherlands, 2008).

25 For general and updated insights into European judicial and legislative issues, see the annual publication of the Yearbook of Muslims in Europe (Brill: published since 2009).

26 Photini Pazartzis, "Le Status des Minorités en Grèce", 38 Annuaire Francais de Droit International (1992), 377; Konstantinos Tsitselikis, "The Legal Status of Islam in Greece”, 44 Die Welt des Islams (2004), 402; Angeliki Ziaka, "Greece. Debates and Challenges", in Maurits S. Berger (ed.), Applying Sharia in the West. Facts, Fears and the Future of Rules of Islam on Family Relations in the West (2013), 125. 
Western courts may occasionally consider rules of Islamic law, for example, the dower of an Islamic marriage, which is considered part of an agreement and as such is treated as a matter of civil contract law, ${ }^{27}$ or Islamic financial rules that have been incorporated in contractual agreements.

\subsubsection{Foreign Law through International Private Law}

The second domain where Sharia law is being practiced in a Western context is international private law. National rules of international private law may require a Western national judge to apply a foreign law to a domestic case, or to recognize a foreign legal situation. If such foreign laws or acts are based on Islamic law, ${ }^{28}$ strictly speaking, the Western court applies Sharia. But if the provisions of these foreign national Sharia laws are considered contrary to fundamental legal principles of a given Western country, the so-called public policy or public order, then such application may be prohibited. Public policy has been invoked in particular in the case of polygamous marriage and unilateral divorce (talaq). For example, in the case of Iranian, Pakistani, or Moroccan nationals in Western countries, the judge of a national Western court must by virtue of the rules of international private law consider the applicability of their Iranian, Pakistani, or Moroccan national family laws. But in the case of polygamy and unilateral divorce, which are valid under these foreign laws, the Western judge may invoke public policy to deny their applicability under the Western jurisdiction.

\subsubsection{Informal Legal Practices}

Informal legal practices make up the third form of Sharia practices in the West. These practices of a legal nature are initiated by individuals, outside state structures or impositions. Examples include Islamic marriages conducted in homes or mosques, private conflict settlement in accordance with Islamic tenets, and the observance of religious rituals. Such informal practices may or may not interact with the domains of national law or international private law. I expect this domain of informal Sharia to gain in importance among Muslims in the

27 Lee Ann Bambach, "Save us from 'Save Our State': anti-Sharia legislative efforts across the United States and their impact", 13 Journal of Islamic Law and Culture (2011), 77; Ursula Günther, Martin Herzog, and Stephanie Müssig, "Researching Mahr in Germany: A Multidisciplinary Approach", 49 Review of Middle East Studies (2015), 23; Nadjma Yassari "Understanding and Use of Islamic Family Law Rules in German Courts: The Example of the Mahr", in Maurits S. Berger (ed.), Applying Sharia in the West. Facts, Fears and the Future of Rules of Islam on Family Relations in the West (2013), 165. 
West, first, because of the increasing religiousness of the new generations, ${ }^{29}$ and a corresponding growing wish to live in accordance to the rules of Islam, and second, because Muslim communities are becoming more established in the Western environment. These communities need to handle their religious affairs autonomously, among others, by creating institutional frameworks independent from their countries of origin.

As noted, little is known about the precise quantity and quality of these practices and manifestations, because research on this topic is scant. But based on research that has been conducted to date, it is possible to construct a general picture of informal Sharia, as practiced in the West. According to this picture, devout Muslims in the West are committed to living in accordance with Sharia, a commitment limited to the following three domains:

1. Religious rules, such as those pertaining to prayer, fasting, burial, dietary laws, and dress code (known in Islam as ibadat);

2. Contractual rules relating to family relations (including marriage and divorce), and to financial transactions (known in Islam as mu'amalat);

3. Interactions within the Muslim community and with non-Muslims (including gender issues, political participation, etc.).

Several observations can be made with regard to these three manifestations of Sharia rules. First, these rules do not include domains of Islamic law like criminal law and state law. Second, this collection of rules appears quite random, both in scope and in content. From an Islamic legal-theological perspective, however, there is an internal logic to it, because these rules share a high ranking in the hierarchy of Islamic rules prescribed by classical legal scholarship: they are explicitly mentioned in the Koran, by the Prophet, or by scholarly consensus, and are therefore the first to be followed by any devout Muslim, and the last to be compromised on. In other words, these rules pertain to the essential substance of Islamic religion.

The third observation is that according to legal standards of most modern states, only the rules relating to family relations and financial transactions can be considered law or legal rules. The other rules pertain to religious rituals or social conduct, and as such have to do with the individuals' freedom to shape their religion and conduct. From an Islamic perspective, however, all human conduct, whether individual or communal, is governed by Sharia.

Fourth, these domains of Sharia pertain to the daily lives of Muslims, and appear to have little to do with the totalitarian schemes of an Islamic state

29 Indicated by various national surveys and studies in Europe. 
or with political views on an Islamic restructuring of Western societies. Of course, such views do exist among some radical Muslims, just as there are Muslim extremists who interpret Sharia as a justification to declare their fellow Muslims heretics, or to call for militant action against alleged Western injustices. Although such people are the source of security concerns, the majority of Muslims in the West uphold a much less radical interpretation of Sharia. It must therefore be clear that for each of the three domains of Sharia rules in the West, we must consider that they can be interpreted by Muslims in liberal as well as conservative, and even in extremist ways. For instance, with regard to the interaction with non-Muslims, we can observe a wide array of practices by Muslims, ranging from participation to segregation and from isolation to aggressive rejection. We will discuss this in more detail in Part III below.

\section{3 (De)constructing Sharia in the West}

The preceding paragraphs provided some crude building blocks to construct a notion of Sharia in the West. We have identified the social-legal domains where Sharia in the West is applicable, but we do not yet have a clear view on how it is applied. To do so requires a legal-anthropological approach. Although the theories and methodologies of such an approach are well developed, they have hardly been applied to Sharia, ${ }^{30}$ and even less so to Sharia in the West. ${ }^{31}$ We therefore have to tailor-make our own approach.

\section{1 $\quad$ The Nature of the Rules}

To start constructing our model, we must begin by reconsidering the term "Sharia," which we have used consequently until now, but which I find problematic for several reasons. First, we have seen that the term "Sharia" has acquired emotive and ambiguous meanings, both for its supporters and opponents, which may interfere with achieving an unbiased view of its exact meaning and practice. Second, in Islamic legal theory, the term "Sharia" stands for a comprehensive legal-theological system that includes a vast scholarly

30 For such a legal-anthropological approach with regard to Sharia in Muslim-majority countries, see Baudouin Dupret, "La sharîa comme référent legislative. Du droit positif à l'anthropologie du droit", 25 Egypte Monde Arabe (1996), 121, and "What Is Islamic law? A praxiological answer and an Egyptian case study", 24 Theory, Culture and Society (2007), 79; Baudouin Dupret, Maurits S. Berger, and Laila al-Zwaini (eds.), Legal Pluralism in the Arab World (Brill, 1999).

31 An exception is the research conducted into the nature of Sharia councils in the UK: see the articles mentioned after "United Kingdom," supra note 8. 
tradition and legal culture. As we have seen, this does not fully correspond with what we observe in the West, where Muslims opt for the observance of only a selection of rules, and perhaps not always do so in agreement with the tenets of Islamic legal theory.

What term should we use then? Some scholars prefer "Islamic law" over Sharia, but this is not satisfactory because law implies a form of state regulation or endorsement, which is not the case for Sharia in the West. ${ }^{32}$ Another option is proposed by legal anthropologists who have correctly pointed out that all guiding principles, whether inspired by state law, religion, organizational bylaws, or parents, are norms. ${ }^{33}$ Some scholars have therefore opted for "Muslim legal norms" and "Islamic norms" when discussing the situation of Muslims in the West. ${ }^{34}$ But I do not find this terminology satisfactory either, because the term "norms" does not do justice to the experience of the devout Muslims who abide by what the Islam prescribes for them to do. From the perspective of the believer, the term "norms" is too contingent and incidental compared to the more comprehensive and commanding nature of what Islam stipulates.

For the purpose of our model I therefore prefer to use the term "rules of Islam," which I define as the set of religiously motivated rules practised by Muslims in the West. Rules of Islam do not represent an absolute and singular Sharia, but a relative notion that depends on the meaning, interpretation, and practice attributed to Sharia by Muslims. As mentioned, this set of rules is not necessarily equal to that of the legal-theological doctrine developed by classical Islamic scholarship. The next step is therefore to come to a clear understanding of where these rules come from.

\subsection{The Production of the Rules}

Although a Muslim individual or community may state that they practice rules of Islam derived from sacred sources, the approach of our model is that the source, the internal motivation, or the justification of these rules is of little relevance because we are interested only in the manifestation of this rule. Similarly,

32 An-Na'im argued succinctly: "Norms regulating family relations can be religious as long as they are not enforced through state law, but once enforced, they become simply state law rules, regardless of their perceived religious sources" (Abdullahi A. An-Na'im, "Religious Norms and Family Law: Is it Legal or Normative Pluralism", 25 Emory International Law Review (2011), 792).

33 See, e.g., William Twining, "Normative And Legal Pluralism: A Global Perspective", 20 Duke Journal Of Comparative \& International Law (2010), 473.

34 Malik opts for the term "Muslim legal and ethical norms" (Maleiha Malik, Muslim Legal Norms and the Integration of European Muslims (European University Institute, 2009)) and Karčic for "Islamic norms" (Harun H. Karčic, "Applying Islamic norms in Europe", 35 Journal of Muslim Minority Affairs (2015), 245). 
the increasing volume of Islamic legal scholarship that regards Muslims in the West (the figh al-aqalliyat) may be of great interest from an intellectual point of view, but tells us little about its practice by Western Muslims. Muslim scholars may come up with all types of Islamic rules tailor-made for Muslims in the West, but we simply do not know whether and to what extent Muslims in the West adhere to these rules. This has to do with the difference between text and practice, whereby both the devout Muslim and the observer may tend to attach greater importance to the text than to what happens in reality. Our model, on the other hand, seeks to facilitate an understanding of the practice of Sharia. Therefore, I want to avoid any claim on what the "right" interpretation or "true" Islam might be, as this would blur our view of what is actually happening in relation to Sharia. My aim is to devise a model that encompasses all different religious-legal realities of Muslim life in the West.

To do so, I turn to the concept of social groups generating or otherwise living in accordance with internal rules. This phenomenon has been extensively studied and theorized by legal anthropologists. ${ }^{35}$ Among the many terms they use to describe such groups, the term "social-legal entity" 36 has the most relevance for the purposes of this model, as it connotes a non-state social entity (individual, communal, or institutional) that determines what rules it practices and what rules need to be practiced. The relation of these rules to the state is thereby of no relevance. Indeed, some of these communal rules may even be contrary to state rules, as is the case with gang rules and many religious rules. What counts is the normativity of the rules within these groups.

Based on these considerations, I suggest to rewrite the definition of sociallegal entity for our purposes as follows: the term "Muslim" in our model denotes Muslim individuals, communities, and institutions that, as separate or amalgamated entities, practice rules that they consider Islamic. (For the sake of clarity, it should be noted that there are also Muslim groups and communities that do not practice such norms.)

35 For example: Bourdieu (“juridical field:" Pierre Bourdieu, "The Force of Law: Toward a Sociology of the Juridical Field", 38 The Hastings Law Journal (1987), 805); Moore ("semiautonomous social field:" Sally F. Moore, "Law and Social Change: The Semi-Autonomous Social Field as an Appropriate Subject of Study", 7 Law and Society Review (1973), 719); Smith ("corporations:" Michael G. Smith, Corporations And Society (1974)); and scholars of legal pluralism (e.g., John Griffiths, "What Is Legal Pluralism?”, 24 Journal of Legal Pluralism (1986), 1; Masaji Chiba, "Other Phases of Legal Pluralism in the Contemporary World", 3 Ratio Juris (1998), 3).

36 See Chiba, supra note 35 . 


\subsection{The Practice of the Rules}

Having determined what we mean by rules of Islam, and who produces these rules, we now come to how they are being practiced. Generally speaking, adherence to rules requires some kind of enforcing agency that, depending on the nature of the rules, can be of a formal nature, such as police or judge, or of an informal nature, such as one's parents, one's peer-group or the sorority's by-laws. In case of Islamic rules, this enforcing agency may be the individual Muslim (who may invoke God as the ultimate enforcing agent), social peer pressure, the religious authorities, or the state. In Muslim majority countries, we see a mixture of all of these, as Islamic rules have become dispersed across the private and public, social and legal domains. Muslim majority countries have infrastructures of adjudication and consultation, and at times enforcement, either as state institutions (courts, state $\mathrm{mufti}$ ) or as part of the religious establishment (institutions like al-Azhar in Egypt). However, such infrastructure is lacking or rare in the West (with the exception of South-East European countries), so that Muslims are left to their own devices, whereby the main problem they face is: Who has the authority to interpret, explain, or adjudicate a rule of Islam? ${ }^{37}$ This explains why so many Muslims in the West refer to Muslim scholars from abroad, and why the Internet plays a prominent role. ${ }^{38}$

In a Western environment, therefore, the practice of the rules of Islam is basically of an informal nature. with the exception of the few aforementioned cases of international private law and some national law rules. That means that adhering to these rules is voluntary: it is the individual Muslim who decides if and how to apply a rule of Islam, and Muslims effectively become their own muftis. ${ }^{39}$ This being the case, the individual voluntarism does not do

37 Peter Mandaville, "Muslim Transnational Identity and State Responses in Europe and the U K after 9/11: Political Community, Ideology and Authority", 35Journal of Ethnic and Migration Studies (2009), 491-506; W. Shadid and P.S. van Koningsveld, "Religious Authorities of Muslims in the West: Their Views on Political Participation", in Wael Shadid and P.S. van Koningsveld (eds.), Intercultural Relations and Religious Authorities: Muslims in the European Union (Leuven: Peeters, 2002), 149-170.

38 See, e.g., Maurits S. Berger, "Buying houses, donating organs and fighting wars - the changing role of muftis", Recht van de Islam (2011); Gary R. Bunt, Islam in the Digital Age: E-jihad, Online Fatwas and Cyber Islamic Environments (Pluto Press, 2003); Bettina Gräf and Jakob Skovgaard-Petersen (eds.), Global mufti: the phenomenon of Yusuf al-Qaradawi (2009); Vit Šisler, "The Internet and the Construction of Islamic Knowledge in Europe", Masaryk University Journal of Law and Technology (2007), 205-217.

39 Described by Peter Mandaville, "Critical Islam and Citizenship among Muslims in Europe \& North America", paper for the international conference on "Migration, Religion and Secularism", Paris, June 17-18, 2005 . 
justice to everyday practice: some Muslims are in need of advice regarding the rules, some are in need of adjudication by third parties in conflicts with fellowMuslims (mostly in matters of marriage and divorce), and some feel restrained in their personal practice of rules by peer pressure. I briefly address these three situations below.

The first two situations, advice and adjudication, explain the need for authoritative Muslim personalities or institutions in Western societies. To date, it seems that such authority is embodied mostly in individuals like imams or scholars. But we have seen that there are few of them in the West, or at least too few to meet the demand for such authority. And of the few bodies that have been established for this purpose, like the so-called Sharia councils in the UK and the figh councils in America, some have received criticism from Muslims for not being representative, or for the pressure that they allegedly exercise, particularly on Muslim women. ${ }^{40}$

Peer pressure is also the main issue in the third situation: Muslims may feel limited in their freedom to interpret and practice certain rules of Islam, or to not follow rules at all, by social pressure or even coercion by other Muslims, such as peers, family, religiously authoritative figures, or the community. This pressure does not apply exclusively to Muslims: individuals in any society are subject to forms of pressure from their environment. Peer pressure in Muslim communities in the West, however, receives considerable public and political attention, mostly with regard to the position of women.

In some instances, this social pressure can be aggressive. Examples are organizations like Sharia4UK and Sharia4Belgium, which have been known for shouting down public meetings on Islam, or the self-proclaimed "Sharia patrols" that harassed passers-by because their dress or behaviour was considered immoral. ${ }^{41}$ Although such extremist Muslims are generally known for their hostility toward Western society, their pressure to conform to stringent interpretations of the rules of Islam is exerted mostly on fellow Muslims.

Peer pressure by fellow Muslims may force certain Muslims to submit against their will to rules of Islam, or to rules that they disagree with. But peer pressure may also force Muslims to call upon rules of Islam as an escape strategy. For example, to avoid parental pressure to marry a candidate of their parents' choosing or to stop their studies in order to get married, young Muslim women

$40 \quad$ Bano, supra note 8; Shachar, supra note 8; Shah-Kazemi, supra note 8.

41 This took place in East London in 2013-14, and in Wuppertal in 2014. No academic writing is yet available on these incidents. See the video posted by the so-called Sharia patrol of its own actions: <http://www.youtube.com/watch?v=nw2w7ACogaY>. For media coverage of these actions, see cNN (<https://m.youtube.com/watch?v=rcsG-u2GtZE $>$ ) and Vice news (<https://news.vice.com/video/londons-holy-turf-war>). 
have been known to invoke certain rules of Islam (this will be further discussed below in Part III).

For the purpose of this model, we conclude that the informal practice of Islamic rules in Western societies is not enforced except by the Muslims themselves. Self-enforcement manifests in several forms, including individual voluntary practice and peer pressure. Between these two are the personalities or bodies that can be given sufficient authority by the Muslims communities to exert forms of enforcement.

Based on these considerations, I define the notion of Sharia in the West as (a) a set of Islam-motivated rules (b) practiced by Muslim social-legal entities (individuals, communities, organizations) in the West, whereby (c) these Muslims are both the defining and the enforcing agency of these rules. The most important conclusion that we can draw from this definition is that Sharia is not something "out there;" it is defined by people through their words and actions.

Note that this definition is not intended to elucidate why Muslims do certain things; it merely determines what they do and how they do it. I believe that this is the only way we can come to a clear and objective evaluation of the socalled Sharia in the West. In doing so, we observe that the Muslims in the West are practicing a selective variety of rules of Islam, ranging from prayer and charity, through marriage and dress codes, to interaction with the non-Muslim environment. These rules are subject to numerous theological interpretations and to various forms of practice, ranging from private and friendly to publicly confrontational and even violent. This amalgam of rules, interpretations, and practices is what we call rules of Islam.

By defining Sharia in this way, we avoid the need to determine whether a rule is or is not Islamic. Sharia may be singular in source but not necessarily in outcome, and it is this outcome where our main interest lies. For example, female genital mutilation (FGM) is considered not Islamic by most Muslim religious authorities and by majority consensus in Islamic orthodoxy, but it is practiced on a wide scale in several Muslim majority countries like Egypt and Sudan, where the practitioners consider it to be a rule of Islam. A similar issue arises with violence perpetrated in the name of Islam: to some Muslims, certain situations may justify or even call for violence, but such violence is condemned by others. In these examples, both sides invoke Sharia to justify their actions. Our model operates under the anthropological thesis that people's actions are the determinant factor. From the perspective of Muslim believers, this may be highly frustrating, because they are in need of religious certainty. 
But the advantage of this approach is that it prevents the observer from becoming mired in discussions about true Islam or real Sharia, and enables him to move on to determining whether a certain action or behavior is acceptable or not, regardless of its religious qualification or justification.

This brings us to the next conclusion, namely that Sharia is a blanket term that needs clarification whenever it is used. Declaring "Sharia" a violation of European values, as stated by the European Court, or banning "Sharia," as has been done in the constitutions of several states in the Us, may be justified with regard to its harsh and intolerant forms promoted or practiced by certain people, organizations, or countries. But the presumably unintended result of such unqualified use of the term "Sharia" is that the condemnation encompasses all rules of Islam, including the religious rituals (like prayer, fasting, and burial) and all practices and interpretations that are in conformity with Western values.

\section{Part II The West}

We now come to the second tier of the model in which we identify "the West" and the nature of its responses to the rules of Islam practiced by Muslims in the West.

\section{Defining the West}

The notion of "the West" is an oddity at best, as its geographic connotation does not hold when one includes Australia, or Japan, or South Africa, or South America; and its connotation as a value system disqualifies any geographic reference. Nevertheless, its use has become so commonplace, especially in connection with the notion of Sharia, that we cannot circumvent it.

For the purpose of this model, I define the West as a geographic region that shares certain histories, features, and values. For the sake of brevity, I refer to three characteristics that stand out. The first is a shared historical heritage that is of European origin, of which the Christian legacy is an important feature. ${ }^{42}$

42 The Christian legacy is often taken as self-evident, usually referred to by such terms as the "Judeo-Christian civilization." A critical historical analysis is found in Mary Anne Perkins, Christendom and European Identity, The Legacy of a Grand Narrative since 1789 (2004). For 
The erosion of this religious legacy through a process of secularization is the second characteristic shared by most of the countries belonging to the West. Especially in response to the presence of Islam in Western societies, the notion of secularism is upheld as a key Western value. ${ }^{43}$ The third characteristic is that in modern times Western countries share certain values that are enshrined in constitutions and conventions, such as political principles (democracy, liberalism, political freedoms) and legal principles (rule of law, constitutional rights, human rights).

Within the context of these shared values and legacies, however, there are distinct differences with respect to the experiences with Muslim communities and immigrants in the various Western countries, their political and legal systems, and their attitudes toward religion. In countries in South-Eastern Europe, for instance, Muslims and consequently, the Islamic infrastructure, are a century-old phenomenon, whereas in other Western countries the presence of Muslims is of recent date. Countries may agree on notions like freedom of religion, but interpret it quite differently, which is why the European Court for Human Rights makes use of the notion of "the margin of appreciation." ${ }^{44}$ And later in this article we will see that Western Europe and the us agree on the notion of secularism as a principal value, but have quite different interpretations on its meaning. These differences, however, are merely the coloring of otherwise common characteristics of the West.

A listing of states that do or do not belong to the West has little relevance to the purpose of our model's analysis. I prefer to use a restricted definition that encompasses only Europe and North America. Others may want to include South America, Australia, and perhaps Russia, Israel, and South Africa. The point, however, is not to focus on individual countries, but to look for certain "Western" commonalities that have a determining influence on responses to the practice of rules of Islam in these societies.

a more intellectual historical approach, see Larry Siedentop, Inventing the Individual. The Origins of Western Liberalism (2014).

43 Jocelyne Cesari and Sean McLoughlin, European Muslims and the Secular State (2005); Sarah Bracke and Nadia Fadil, Islam and Secular Modernity under Western Eyes: A Geneaology of a Constitutive Relationship (2008).

44 Tom Lewis, "What Not to Wear: Religious Rights, the European Court, and the Margin of Appreciation", 56 The International and Comparative Law Quarterly (2007), 395; Raffaella Nigro, "The Margin of Appreciation Doctrine and the Case-Law of the European Court of Human Rights on the Islamic Veil", 11 Human Rights Review (2010), 531; Janneke Gerards, "Pluralism, Deference and the Margin of Appreciation", 17 European Law Journal (2011), 80. 
If we were to draw up a list of rules of Islam practiced by Muslims in the West, and would confront each rule with the question "Do Western values allow this rule of Islam or not, and why?" we would be presented with a broad array of answers. At face value, these responses would appear to be diverse. First, there is a difference between the many Western countries. For example, in some Western countries police officers and teachers may wear a headscarf, whereas in others it is strictly forbidden. Second, the various rules of Islam elicit different reactions: some rules are considered controversial, like face veils and certain forms of family law, whereas others are applauded or even embraced, such as Islamic financial instruments. ${ }^{45}$

Within this myriad of often-conflicting Western reactions, we may discern two general but distinct responses. The first I call the "political-legal response," which corresponds to all norms generated by law and court rulings, and can be paraphrased as "this is how we have organized our society." The second I call the "cultural-religious response," which corresponds to all norms generated by the dominant political, cultural, and social norms shared by the majority of society, and can be paraphrased as "this is how we do things here." These two responses enable us to obtain a comprehensive picture of the West and its interaction with rules of Islam.

\subsection{Political-Legal Response}

Western countries share a system of political and civil liberties and institutions, most of which are enshrined in constitutions and treaties. These include the rule of law, democracy, human rights, and (individual) freedoms. I use the term political-legal response to denote all reactions toward manifestations of rules of Islam that invoke these political and legal values. In our case, we are interested in such responses to the informal practice of rules of Islam. For this, we first need to obtain a better view of the Western political-legal response to religion in general. Although recent publications indicate shifts in the legal paradigm owing to emergent cultural and religious pluralisms, ${ }^{46}$

45 This paradox has been dubbed "good Sharia - bad Sharia" (Ann Black and Kerrie Sadiq, "Good and Bad Sharia: Australia's Mixed Response to Islamic Law", 34 UNSw Law Journal (2011), 383).

46 See, e.g., Ralph Grillo et al., Legal Practice and Cultural Diversity (2009); Jorgen S. Nielsen and Lisbet Christoffersen (eds.), Shari'a As Discourse. Legal Traditions and the Encounter with Europe (2010); Prakash Shah, Marie-Claire Foblets, and Mathias Rohe (eds.) Family, Religion and Law: Cultural Encounters in Europe (2014). 
we can discern a few basic features of this response that are of a structural nature. ${ }^{47}$

The most important of these features is that in Western countries, religion is subordinate to the overall political and legal national structure. Political and legal concepts like freedom of religion and separation of church and state are legal means to regulate the leverage that religion may enjoy in a particular society. Admittedly, countries differ in the elaboration of these fundamental principles. For example, freedom of religion means no state involvement in some countries, while it is upheld in other countries by means of active state support. In the latter case, formal state recognition of a religious community is needed for these communities to establish their theology faculties, to receive funds to pay the salaries of their clergymen, to maintain their places of worship, or otherwise to be recognized as a formal counterpart of the state.

Within these different modalities, religious communities in Western societies have maintained their institutional and legal infrastructure, parallel to that of the state, and are mostly allowed to do so as part of their freedom of religion. ${ }^{48}$ Consequently, in most Western countries, Catholic, Protestant, Orthodox and Jewish communities have established so-called religious tribunals to regulate their religious family affairs autonomously, outside the state legal system. In most Western countries, however, their decisions have no legal power and are to be followed on a voluntary basis, a voluntarism that may be subject to peer or community pressure, as noted above.

\subsection{Religious-Cultural Response}

The proposed model holds that many controversies regarding rules of Islam in Western societies are not of a political-legal nature, but are prompted by societal and cultural objections raised by the dominant normative culture of a particular society. Although such generalizations do not do justice to the heterogeneous and pluralist nature of many Western societies, a strong majority voice has recently emerged in these societies laying claim to "traditional" or "national" values. Insofar as these values are based on local custom, a national tradition or a dominant social order, but not on the national political-legal framework, I refer to them as cultural-religious values. The voice referring to these values is often raised in discussions on pluralism, multiculturalism, and liberties, and is most prominent when it comes to matters of Islam and, in

\footnotetext{
47 Christopher N. Doe, "A Sociology of Law on Religion Towards a New Discipline: Legal Responses to Religious Pluralism in Europe", 152 Christian Law Review (2004), 68.

48 See, e.g., Russell Sandberg et al., "Britain's Religious Tribunals: 'Joint Governance' in Practice", 33 Oxford Journal of Legal Studies (2013), 263.
} 
particular, Sharia. This voice is the "religious-cultural response" which, in the absence of any legal or other concrete reference, can best be characterized by "this is the way we do things here."

For example, with regard to religion, secularism is often referred to as fundamental to Western societies, and as such in contradiction with the newly arrived public manifestations of Islam in the West. ${ }^{49} \mathrm{I}$ argue, however, that the issue is not secularism, but the cultural tradition of regulating religion. In Europe, the notion of secularism has developed as a dominant public and political culture that is unappreciative of overt manifestations of religiosity. In the us, however, a different tradition of secularism exists, where religion plays a prominent role in the public and political domain. ${ }^{50}$ Manifestations of religion, by Islam or any other religion, are therefore likely to clash with the European way of handling religion, but less so with the American way. The clash is much less prominent, however, if secularism is defined as a political-legal institution of separating state and religion. It is precisely this separation that is embraced by many European Muslims because it guarantees their freedom to practice their faith according to their own wishes and without state interference. ${ }^{51}$

Although European countries take pride in their secularism, in 2005, in the final phase of the European Union Convention working on the "EU Constitution," several European government leaders suggested mentioning in its preamble the European identity as Judeo-Christian. ${ }^{52}$ The proposed amendment

49 See, e.g., Talal Asad, Formations of the Secular: Christianity, Islam, Modernity (2003); Cesari and McLoughlin, supra note 43; José Casanova, "Religion, European secular identities, and European integration", 27 Transit (2004), 1; Olivier Roy, Secularism confronts Islam (2007); Armando Salvatore, "Power and Authority within European Secularity: From the Enlightenment Critique of Religion to the Contemporary Presence of Islam”, 96 Muslim World, special edition "Islam and Authority in Europe" (2006), 543.

5o For comparative analyses, see, e.g., Peter L. Berger, Grace Davie, and Effie Fokkas, Religious America, Secular Europe?: A Theme and Variation (Ashgate Publishing, Ltd, 2008); Jocelyne Cesari, When Islam and Democracy Meet: Muslims in Europe and the United States (2004); Barbara D. Metcalf, Making Muslim Space in North America and Europe (Univ. of California Press, 1996); Pamela I. Jackson and Peter A. Zervakis, The Integration of Muslims in Germany, France and the United States: Law, Politics and Public Policy (2004 annual meeting of the American Sociological Association <http://citation.allacademic.com/ meta/p_mla_apa_research_citation/1/o/9/2/3/p109230_index.html>).

51 Jytte Klausen, The Islamic Challenge: Politics and Religion in Western Europe (Oxford Univ. Press, 2005), 204ff.

$5^{2}$ Madeleine Heyward, "What Constitutes Europe? Religion, Law and Ideology in the Draft Constitution for the European Union", Hanse Law Review (2005), 227-235; Iordan Bărbulescu and Gabriel Andreescu, "References to God and the Christian Tradition in 
did not come to pass, but it illustrates the frequently emotion-ridden debate concerning the extent to which Islam can be considered part of European civilization and identity. ${ }^{53}$

\section{The Two Responses Applied: West vs. Sharia}

The combination of the political-legal and religious-cultural responses helps us make sense of the different, and at times opposing responses to rules of Islam. For example, the law may explicitly allow the building of mosques despite nationwide opposition; or the law does not prescribe that hands need to be shaken when greeting, yet this may be considered an insult by local custom; or, in countries like Kosovo and Albania, wearing the headscarf is not allowed at universities, but it is accepted as part of the national culture of these countries. At times, political-legal and cultural-religious responses concur: interestfree "Islamic" finance is implicitly allowed by law as part of the freedom of contract, and is accepted in most Western countries; at the same time, polygamy is neither allowed by law nor considered acceptable by Western cultures.

Based on these examples, we can draw up a matrix that identifies each rule of Islam on the basis of being allowed (or not) by prevailing state law and court rulings, and being accepted (or not) by the dominating normative culture (see table on next page).

This matrix of political-legal and religious-cultural responses is not intended to be exhaustive, but merely illustrative. And granted, this matrix is sketchy and prone to nuance and interpretation: especially the normative aspect of the cultural-religious dimension deserves a more complex answer than a simple yes or no. But the matrix may help us understand Western responses to "Sharia." We see that quite some rules of Islam get two opposing responses from their Western environment: they can be explicitly or implicitly allowed by law, but at the same time not considered acceptable from a cultural or social perspective. This explains the confusion in debates, when the often-heard argument "that is not allowed" implies a legal prohibition, whereas in practice it

the Treaty Establishing a Constitution for Europe: An Examination of the Background", 8 Journal for the Study of Religions and Ideologies 24 (2009), 207-223.

For the argument that Islam is more part of European identity and culture formation than generally assumed, see Richard Bulliet, The Case for an Islamo-Christian Civilization (Columbia Univ. Press, 2006) and Maurits Berger, A Brief History of Islam in Europe, supra note 11. 


\begin{tabular}{|c|c|c|c|}
\hline $\begin{array}{l}\text { Examples of } \\
\text { Islamic rules }\end{array}$ & $\begin{array}{l}\text { Allowed } \\
\text { (political-legal } \\
\text { response) }\end{array}$ & $\begin{array}{l}\text { Accepted } \\
\text { (cultural-religious } \\
\text { response) }\end{array}$ & Western countries \\
\hline Ritual burial & Yes (explicit) $)^{(*)}$ & Yes & Most Western countries \\
\hline \multirow[t]{2}{*}{ Ritual slaughter } & Yes (explicit) & (debated) & Most Western countries \\
\hline & No (explicit) & (debated) & Denmark, Switzerland, Poland \\
\hline \multirow[t]{2}{*}{ Minaret } & Yes (explicit) & (debated) & Most Western countries \\
\hline & No (explicit) & No & Switzerland \\
\hline \multirow[t]{2}{*}{ Sharia court } & Yes (explicit) & Yes & Greece (Eastern Thrace) \\
\hline & No (explicit) & No & Most Western countries \\
\hline \multirow[t]{2}{*}{ Sharia council } & Yes (explicit) & No & UK \\
\hline & Yes (implicit) & No & Most Western countries \\
\hline \multirow[t]{2}{*}{ Face veil } & Yes (implicit) & No & Most Western countries \\
\hline & No (explicit) & No & France, Belgium \\
\hline $\begin{array}{l}\text { Not shaking } \\
\text { hands }\end{array}$ & Yes (implicit) & No & Most Western countries \\
\hline \multirow[t]{2}{*}{ Islamic will } & Yes (implicit) & Yes & UK \\
\hline & & No & Netherlands \\
\hline \multirow{2}{*}{$\begin{array}{l}\text { Headscarf at } \\
\text { university }\end{array}$} & Yes & Yes & Most Western countries \\
\hline & No (explicit) & Yes & Albania, Kosovo \\
\hline \multirow{2}{*}{$\begin{array}{l}\text { Headscarf as } \\
\text { police uniform }\end{array}$} & No (explicit) & No & Most Western countries \\
\hline & Yes (explicit) & Yes & UK \\
\hline Islamic finance & Yes (implicit) & Yes & Most Western countries \\
\hline Polygamy & No (explicit) & No & Most Western countries \\
\hline \multirow[t]{2}{*}{ "Sharia" } & Yes (implicit) & No & $\begin{array}{l}\text { Archbishop of Canterbury; } \\
\text { Lord Chief Justice of England }\end{array}$ \\
\hline & No (explicit) & No & ECHR; several US states \\
\hline
\end{tabular}

$\left({ }^{*}\right)$ Explicit vs. implicit: a state law or by-law may explicitly mention a rule of Islam (for example, the burqa ban in France or the ban on ritual slaughter in Denmark), or it may implicitly allow such a rule (for example, Islamic finance as part of the freedom of contract). 
is based on customary dos and don'ts. The political-legal "that is not allowed" then becomes intermingled with the cultural-religious response "that is not how we do things here." Let us elaborate a few Islamic rules to illustrate this mixture of political-legal and cultural-religious responses.

The first example is that of Sharia courts. The only Sharia courts that are part of the national legal system in the West exist in the Greek province of Western Thrace. ${ }^{54}$ In view of the long-standing presence of Protestant, Catholic, and Jewish religious tribunals in Western societies, it would appear that from a political-legal point of view an Islamic tribunal should be acceptable. But the cultural-religious response against Islamic tribunals is the dominant one. Note that the arguments against such tribunals are seldom levelled against the religious tribunals of the other religions. ${ }^{55}$

Another example is the so-called burqa ban, or prohibition against wearing the full-face veil in the public domain. Bills to this effect have been tabled in France, Belgium, the Netherlands, and Spain in $2010 .{ }^{56}$ The bill was not pursued in the Netherlands and Spain, but in France it became law in 2010 and in Belgium in $2011 .{ }^{57}$ The reasons adduced by the legislators for such a ban were quite diverse, including such political-legal values as equality, freedom, and human dignity, but pertained mostly to cultural-religious values like "rejection of society," "problematic for integration," "burqas are not mentioned in the Quran,"

$54 \quad$ Supra note 26.

55 An illustrative case is Ontario, where family arbitration tribunals for Jews, Christians, and other religious and indigenous communities had existed but were abrogated in 2007, after lengthy discussions on thenature of such tribunals, when Muslimsalso wanted to establish a similar tribunal. See Bakht, supra note 8; Marion Boyd, Dispute Resolution in Family Law:Protecting Choice, Promoting Inclusion (Review Report to the Attorney General and Minister Responsible for Women's Issues, Ontario, Canada, 2004<https://www.attorneygeneral.jus.gov .on.ca/english/about/pubs/boyd/executivesummary.pdf>); Sherene H. Razack, "The 'Sharia Law Debate' in Ontario: The Modernity/Premodernity Distinction In Legal Efforts To Protect Women From Culture", 15 Feminist Legal Studies (2007), 3; James Thornback "The Portrayal of Shariain Ontario", AppealRevue of CurrentLawandLegalReform (2005).

$5^{6}$ Maurits S. Berger, "Rechtsgronden voor een verbod op de gezichtsbedekkende sluier in Frankrijk, België en Nederland", 3 Tijdschrift voor Religie, Recht en Beleid (2010), 96. The number of women wearing such full-face veils was estimated at 250 in Belgium (population of 13 million), 400 in the Netherlands (population of 17 million), and between 400 and 2,00o in France (population of 66 million).

57 France: Law No. 2010-1192 of 11 October 2010. Belgium: Wet van 1 juni 2011 tot instelling van een verbod op het dragen van kleding die het gezicht volledig dan wel grotendeels verbergt, Belgisch Staatsblad 13 juli 2011. 
"oppression of women," and "disruptive to public order."58 Voices critical of such ban framed their arguments in strictly political-legal terms (violation of individual autonomy and of equal treatment), ${ }^{59}$ but the cultural-religious argument appeared more decisive: this is not how we do things here. ${ }^{60}$

A last example is the ban on "Sharia." We have discussed the views of the European Court of Human Rights on "Sharia" in the Introduction. Several us states went further by prohibiting "Sharia" in its entirety. This started with the "Save our State" amendment in Oklahoma, in 2010. ${ }^{61}$ Some other states explicitly banned "Sharia law" from being applied by their courts, ${ }^{62}$ others applied a more general ban on any religious or foreign law, and a third category of states banned foreign laws that do not provide the same protections as us law does. ${ }^{63}$ Two issues stand out here. First, none of these bills define what they mean by "Sharia." Second, there was no history of problems with Sharia or any Islamic rule in any of these states: "Sharia" appeared to have been conceived not as a practice that needed to be stopped, but to be prevented from ever taking root. ${ }^{64}$ Although the political-legal response (freedom of religion, rule of law,

$5^{8}$ Berger, supra note 56. For France, see the two proposed bills: Projet de loi interdisant la dissimulation du visage dans l'espace public (No. 2520, 19 May 2010) and Proposition de loi visant à fixer le champ des interdictions de dissimuler son visage liées aux exigencies des services publics, à la prévention des atteintes à l'ordre public (No. 2544, 20 May 2010).

59 This opposition was voiced by the State Councils of France and the Netherlands: Conseil d'Etat, Etude relative aux possibilités juridiques d'interdiction du port du voile integral, 25 mars $2010<$ <ww.conseil-etat.fr/cde/media/document/avis/etude_vi_30032010.pdf>; Raad van State, zaaknummer Wo3.07.0219/II, 21 September 2007.

6o The European Court of Human Rights acknowledged the French and Belgian bans in 2014 and 2017, respectively, on the basis of the principle of "living together" (for France, see S.A.s. v. France, 1 July 2014, and for Belgium, see Belcacemi and Oussar v. Belgium, and Dakir v.. Belgium, both 11 July 2017).

61 H.R.J Res. 1056, 52nd Leg., 2d Reg. Sess. (Okl. 2010).

62 By 2015, these states included Alabama, Arizona, Kansas, Louisiana, North Carolina, South Dakota, Tennessee, and Texas. There were other states that had passed similar laws, but those were overturned in court. It remains to be seen whether the mentioned states can uphold their laws in court.

63 See for discussion of these different alternatives: Muhammad Elsayed, "Contracting Into Religious Law: Anti-Sharia Enactments And The Establishment And Free Exercise Clauses", 20 Geo. Mason Law Rev 937 (2013), 943-944; Steven M. Rosato, "Saving Oklahoma's 'Save Our State' Amendment: Sharia Law in the West and Suggestions to Protect Similar State Legislation from Constitutional Attack", 44 Setton Hall Law Review (2014), 659, $685^{-692 .}$

64 In Oklahoma, $82 \%$ of lawmakers and $70 \%$ of Oklahoma citizens who voted in favour of the amendment thought it necessary to launch a preemptive strike against any Islamic law infiltrating Oklahoma; Jaron Balou, "Sooners vs. Shari'a: The Constitutional and 
unambiguity of legislation) would rule against such a ban, these arguments were overruled by the religious-cultural response. ${ }^{65}$

\section{The Two Responses Combined: Majority Control}

Combining the two Western responses shows that the debates about Sharia cover wider issues than law and legal institutions. But there is more to consider. In its responses, the West, like any other state system, represents a normative system that is enforced through political, legal, and social majority control. ${ }^{66}$ The term "majority control" refers to the fact that these systems determine what is allowed and what is not, legally as well as culturally. And this, now, is a key factor in the interaction between "Sharia" and the "West".

In Western states and societies, Muslims constitute a minority with little if any influence on majority control. Although it is at times suggested by critics of Islam and Sharia that the West is struggling to withstand an emerging Sharia ("creeping Sharia"), in reality Western legal systems do not have to adapt or otherwise give in to rules of Islam. Even if one were of the opinion that rules of Islam somehow need to be accommodated by Western legal systems, ${ }^{67}$ such accommodation would be by choice of these systems and not by imposition of rules of Islam or by Muslims. Muslims wishing to apply any Islamic rule of their choosing are always dependent on the possibilities and preclusions of the Western normative context.

Societal Problems Raised by the Oklahoma State Ban on Islamic Shari'a Law", 30 Law and Inequality (2012), 310, 316-318.

65 The notion of "infiltration" or "creeping Sharia" is heard more frequently in the us than in Europe.

66 This definition is based on the notions of "legal system" and "legal culture" as used by Chiba, supra note 35; Mark van Hoecke and Mark Warrington, "Legal Cultures, Legal Paradigms and Legal Doctrine: Towards a New Model for Comparative Law", International \& Comarative Law Quarterly (1998), 47; Ugo Mattei, "Three Patterns of Law: Taxonomy and Change in the World's Legal Systems", 45 American Journal of Comparative Law (1997), 5; David Nelken, "Comparing Legal Cultures", in Austin Sarat (ed.), The Blackwell Companion to Law and Society (John Wiley and Sons, 2004), 113-130; Csaba Varga (ed.) Comparative legal cultures (Dartmouth, 1992).

67 Marie-Claire Foblets, Jean-Francois Gaudreault-Desbien, and Alison Dundes Renteln, The Response of State Law to the Expression of Cultural Diversity (2010); Malik, supra note 34; McGoldrick, supra note 9; Prakash Shah, "Transforming to Accommodate? Reflections on the Shari'a Debate in Britain", in Ralph Grillo et al. (eds.), Legal Practice and Cultural Diversity (2009), 73-92; Bryan S. Turner and Berna Z. Arslan, "Shari'a and legal pluralism in the West", 14 European Journal of Social Theory (2011), 139. 
It appears, therefore, that the power relations between the Western legal system and the rules of Islam represent, in the words of M.B. Hooker, the "dominant" vis-à-vis the "servient" rules. ${ }^{68}$ Although this point may seem selfevident, it needs emphasis because the issue of Sharia vs. the West is often discussed as if it were a conflict between two equal entities. And that is definitely not the case. The power relations work in favour of the Western legal system. This shows, for instance, in the increasing tendency in Western European countries to "defend" cultural practices by means of legislation, a defense often aimed against rules of Islam, resulting in laws and by-laws concerning dress code (headscarf) or social interaction (shaking hands, burqa). The culturalreligious response is then being transformed into a political-legal response.

Security as a Third Response?

The previous paragraph did not address a third, and perhaps the most dominant contemporary response to Sharia, which is the security response. Sharia as such, or in some of its manifestations, is at times perceived as a threat to the legal order, to social cohesion, or to national security in general. The response in this case is not political-legal or religious-cultural, but one of selfpreservation or even self-defense. Is this a third category of Western responses that we need to consider? In my opinion, we do not, because this response is of a different order. The political-legal and cultural-religious responses stem from strongly-held values; security, by contrast, is a self-defense response; it is not a value or based on a value, but rather serves to protect those values. This is not intended to reject such a response; on the contrary, the self-preservation of any nation or society is a factor that drives human behavior. I am, however, more concerned here with providing an analytical tool for the underlying factors (what kind of Sharia are we talking about, and what is the nature of the responses to it from the Western environment) than with the security policies that may or may not follow from such analysis. I therefore leave security considerations out of the model.

Based on the above, I define the West in this model as (a) a normative political, legal, and social system that (b) shares typical "Western" features, histories

68 M.B. Hooker, Legal Pluralism: An Introduction to Colonial and Neo-Colonial Laws (1975). 
and values, and (c) is enforced through majority control. In the case of rules of Islam, the Western response can often be reduced to either political-legal values that are enshrined in treaties and constitutions, or to religious-cultural values that can be best summarized as "that is how we do things here." The conflict with rules of Islam is mostly with the latter: although many rules of Islam are perfectly in accordance with Western political-legal values, or allowed by them, they are often considered to be in conflict with religiouscultural values. I argue that most Western conflicts with Islam that make headlines are, apart from Islam-motivated terrorist attacks, issues related to social behavior. In some cases, such as the burqa ban in France and Belgium, and the Sharia ban in several us states show, these have been legalized.

\section{Part III Responses by Muslims}

The model proposed in this article is based on a dialectic: Muslim social-legal entities want to live in accordance with certain rules of Islam, prompting Western legal systems to respond, which in turn creates counter-responses by Muslims. This counter-response is what I will discuss in this last section of the article.

The cases discussed in the previous section show that most responses to Sharia-related matters are not of a political-legal nature. Indeed, the politicallegal response is often favourable to rules of Islam and their institutionalization, but this seldom is a convincing argument. Manifestations of rules of Islam receive mostly a negative religious-cultural response. The alleged infringement by these rules on religious-cultural values, or its contradiction to such values, is often perceived in such manner that the public or politicians ask for the protection of these values, at times even under the aegis of national security.

Two effects of this response on Muslims are apparent. On one hand, Muslims in the West embrace the Western political-legal values, at times even more than their non-Muslim peers do. ${ }^{69}$ That is not surprising, because these

69 Gallup World Poll, Special Report: Muslims in Europe (2007); Gallup, Interfaith Coexist Index 20o9: A Global Study of Interfaith Relations (2009), 23-24; European Union Agency for Human Rights, Second European Union Minorities and Discrimination Survey (EU-MIDIS II) Muslims - Selected findings, 2017. See also Jytta Klausen, supra note 51. 
values guarantee the freedom to live in accordance with one's religious and cultural particularities. Hence the paradox that Western political-legal values create the possibility for living in accordance to Sharia. This is what the Archbishop of Canterbury and the Lord Chief Justice of England and Wales meant in their speeches in 2008. ${ }^{70}$

It should not be surprising, therefore, that many Muslims in the West perceive the Western response being based on double standards: the freedoms that the West embraces are restricted as soon as it comes to Islam and Muslims. ${ }^{71}$ This second effect is enhanced by initiatives in some Western countries to legalize certain cultural-religious values, elevating them to the level of political-legal values, such as the ban on minarets in Switzerland or the burqa ban in France and Belgium.

\section{2 \\ The Effect of Western Responses on Rules of Islam}

Muslims in the West are keenly aware that what they want with respect to the rules of Islam may at times not be allowed by law, often because of political, legal, emotional, and cultural objections to Sharia. A few Muslims claim their political-legal rights by aggressively invoking Sharia, but most maintain adherence to rules of Islam with caution and trepidation. With this is mind, and allowing for generalizations, it is possible to point out five ways in which Muslims cope with rules of Islam in light of the array of Western responses: rejection, adoption, adaptation, conformity, and incompatibility.

\subsection{Rejection}

Some rules of Islam are not pursued at all by Muslims in the West. What these rules are depends on the individual Muslim (as noted, some may not be religious at all), but the corporal punishments for certain crimes under Sharia may serve as an example. ${ }^{72}$ The punishments for these crimes are explicitly mentioned in the Quran and are therefore considered theologically mandatory.73 But there is no evidence that Muslims in the West have a desire to practice

\footnotetext{
70 Supra note 3.

71 There is no literature to support this view, but a quick scan of the Internet shows that this sentiment is largely shared by Muslims.

72 These crimes are: theft, intake of alcohol, highway robbery, adultery, and false accusation of adultery. Murder and apostasy are also included, but not specifically mentioned in the Quran as crimes.

73 Nevertheless, as these punishments are deemed explicitly obligatory under Islamic orthodoxy, it is one thing for Muslims to deem them not applicable, but altogether another to condemn or abolish them, which would imply the abrogation of a part of sacred
} 
them. This observation, however, is not substantiated by surveys or other research, and the hundreds of Westerners who had gone to join Isis in Syria may be proof of the contrary.

\subsection{Adoption}

With regard to some rules of Islam, no compromise is considered possible: they are to be adopted in full and unconditionally observed. These rules, which pertain to the core of Islamic orthodoxy, are of two kinds: most of them apply to the relations between the believer and God (ibadat), and some of them to relations between men (mu'amalat).

The ibadat are the rules concerning rituals such as prayer, fasting, slaughter, burial, and dress code. Problems posed by Western responses are mostly of a practical and cultural nature: prayer may not always be allowed at the workplace or one may not interrupt work precisely at prayer time; headscarves and other Islamic attire may not be permitted in certain workplaces. The opposition to some religious rituals in Western Europe is becoming increasingly more principled, such as ritual slaughter (considered harmful to animal welfare $)^{74}$ and male circumcision. ${ }^{75}$ Because the rules of ibadat represent the essence of Islamic belief, Muslims consider any restriction thereof as a de facto prohibition of Islam.

Some Muslims advocate the adoption in full of the rules of mu'amalat, such as the rules of marriage and divorce, gender differentiation, and the ban on interest, but this may not always be feasible. Although all these rules are legally allowed in Western societies, that is, they are not prohibited, they may encounter some practical obstacles: religious marriage and divorce are not recognized by state courts; gender separation can be practiced in private but not in public or in the workplace; and the rejection of financial interest means forfeiting savings account, mortgages, and the like.

If Muslims feel compelled to observe the rules of Islam that are not allowed or accepted in Western societies, they have two options: either they retreat into isolation, possibly within their own community, just as some of their Christian, Jewish, and other orthodox peers in the West have done, or

scripture. This explains the intermediary position of Tariq Ramadan, when he called for a "moratorium" on these punishments (posting of 5 April 2005 on tariqramadan.com).

74 Carla M. Zoethout, "Ritual Slaughter and the Freedom of Religion: Some Reflections on a Stunning Matter", 35 Human Rights Quarterly (2013), 651.

75 See, e.g., Resolution No.1952 of 2013 by the European Parliament, which recommends further legislative and policy measures to reinforce the child's right to physical integrity. Among the violations of such integrity is mentioned "the circumcision of young boys for religious reasons." 
they try to have the Western legal systems amended so that these accommodate the rules of Islam. Examples of the latter are the amendments of Western laws on ritual burial and ritual slaughter (although the latter is currently being reviewed in several European countries). Similarly, amendments of labor laws are occasionally made or considered to accommodate Islamic religious holidays. The most conspicuous amendments have been the changes in English fiscal law since 2003, to accommodate Islamic financial instruments that are based on a ban on interest (such as mortgages and student loans). ${ }^{76}$ Furthermore, the Western private financial sector provides comprehensive 'Sharia-compliant' financial services. ${ }^{77}$

A third option is the one preferred by extremists, who enforce their preferred rules of Islam in any way possible regardless of circumstances, resorting to coercion and even violence against Muslims as well as non-Muslims.

\subsection{Adaptation}

Muslims who adhere to a strict observation of rules of Islam are unwilling to make the slightest adaptation to these rules. But believers with a more liberal inclination may be open to considering the modalities of interpretation. This is where the newly developed scholarship of figh al-aqalliyat (Islamic law for minorities) and the notion of maqasid al-Sharia (purposes of Sharia) play important roles. ${ }^{78} \mathrm{~A}$ few examples are illustrative:

a) A Muslim employee in a fast food restaurant asked whether he was allowed to sell pork sausages. In a fatwa, he was told that as a basic rule selling or handling pork is forbidden and that he should try to make working arrangements to avoid it. If this was not possible, he should find other employment. But if he had no employment alternative, he was told: "you

76 Michael Ainley et al., Islamic Finance in the UK: Regulation and Challenges (2007); Yusuf Karbhari, Kamal Naser, and Zerrin Shahin, "Problems and Challenges Facing the Islamic Banking System in the West: The Case of the UK", 46 Thunderbird International Business Review (2004), 521.

77 Kilian Bälz, "Islamic Finance for European Muslims: The Diversity Management of Shari'ah-Compliant Transactions", 7 Chicago Journal for International Law (2006), 551; McGoldrick, supra note 9.

78 Jasser Auda, Maqasid al-Sharia as Philosophy of Islamic Law: A Systems Approach (International Institute of Islamic Thought, 2008); Dilwar Hussain, "Muslim Political Participation in Britain and the 'Europeanisation' of Fiqh”, 44 Die Welt des Islams (2004), 376; Mohammad H. Kamali, Maqasid al Sharia Made Simple (The International Institute of Islamic Thought, 2009). See also Tariq Ramadan, Radical Reform. Islamic Ethics and Liberation (Oxford Univ. Press, 2009). 
have to continue to work if you do not have another sufficient source of income."79

b) Are Muslims allowed to participate in the elections and government of a non-Muslim majority country? Classical Islamic legal scholarship is not specific on the position of Muslims in a non-Muslim majority environment, as this situation did not arise at the time this scholarship was developed. On one hand, there has been the situation of the Prophet Mohammed sending his followers to the Christian kingdom of Ethiopia to take refuge from persecution in Mecca. On the other hand, Islamic scholarship maintains the rule that "Islam supersedes and should not be superseded," in other words, a Muslim should never be subject to nonMuslim authority. The advocates of minority figh acknowledged both rules, but introduced the "interest" (maslaha) of the Muslim as a third consideration that overrides all others, and deemed participation of Muslims in non-Muslim elections and government permissible if "the interests of Muslims can only be served by this participation." ${ }^{80}$

c) In a controversial ruling, the European Council for Fatwa and Research stated that a mortgage was allowed for Muslims living in the West with the following argument: because it is almost impossible to buy a house in the West without a mortgage, and buying a house is a way of upward social mobility by moving into better neighbourhoods, Muslims would deprive themselves of improving their lives if they were not allowed to take a mortgage. This, the Council argued, would be contrary to the primary purpose of the Sharia, which is to enable Muslims to prosper in life. ${ }^{81}$

These are three examples of a more liberal interpretation of rules of Islam. Other Muslim scholars, however, may reach different conclusions. ${ }^{82}$ This diversity in opinions is confusing to some Muslims (as well as to most non-Muslims), but to others it is representative of the flexible and democratic nature of Sharia: Islamic legal science accepts that more than one interpretation is possible,

\footnotetext{
79 European Council of Fatwa and Research, Fatwa Nr. 14, 1999 (second session) in Altikriti and Al-Ubaydi (eds.) Fatwas of European Council for Fatwa and Research (Islamic Inc., n.d.).

8o Alexandre Caeiro, "The European Council for Fatwa and Research", paper presented at the Fourth Mediterranean Social and Political Research Meeting, Florence, 2003.

81 Alexandre Caeiro, "The social construction of shari'a: bank interest, home purchase, and Islamic norms in the West", 44 Die Welt des Islams (2004).

$82 \quad$ See literature, supra note 38 .
} 
depending on time and circumstance, and it is up to believers to choose the scholarly interpretation that best fits their personal beliefs.

\subsection{Conformity}

Another accommodation to Western responses occurs when the rule of Islam is considered to be in conformity with the corresponding rule in the Western legal system, so that there is no need for a separate invocation or application of that rule of Islam. For example, it has been suggested that if one were to fulfil the conditions of an Islamic marriage (offer and acceptance of marriage in the presence of two male Muslim witnesses $)^{83}$ when concluding a civil marriage, a separate Islamic marriage is not needed. ${ }^{84}$

Similarly, it could be argued that a divorce obtained in most Western legal systems is not much unlike an Islamic divorce (talaq): even though the Western divorce is factually pronounced by the judge, both a Western and Islamic divorce are effectively unilateral acts, as the divorce can be obtained by the mere wish of one of the spouses, without any legal conditions. A distinct difference is that in the Western systems both spouses have this unilateral right of divorce while the Islamic talaq is the exclusive right of the husband, but under Islamic law the husband can grant this right to the wife, ${ }^{85}$ so that the distribution of divorce rights conforms to most Western divorce laws. ${ }^{86}$

Another example of conformity is international relations and international law, which are considered compatible with Sharia because their mechanics are not different from Sharia or contrary to it. All modern Muslim states make this tacit acknowledgement. ${ }^{87}$ This logic can be taken further, as was done in Egypt in 1995: when a team of leading Muslim clerics declared that 95\% of Egyptian laws were "not in violation" of Sharia, the state declared that this conclusion justified the statement that Egyptian laws were, effectively, Sharia. ${ }^{88}$

83 The presence of an imam is customary, but not a prerequisite under Islamic law.

84 This position is held, among others, by mufti Ebrahim Deassai; Vit Sisler, "European courts' authority contested? The case of marriage and divorce fatwas on-line", 3 Masaryk University Journal of Law and Technology (2009), 51, 65-66.

85 This is the cessation (tafwid) of the talaq.

86 Strictly speaking, Islamic divorce becomes effective upon its pronunciation by the spouse, whereas in Western laws it is the court that pronounces the divorce.

87 Maurits S. Berger, "Islam and Islamic Law in International Relations", in Marie-Luisa Frick and Andreas Th. Mueller (eds.), Islam and International Law. Engaging Self-Centrism from a Plurality of Perspectives (Martinus Nijhoff Publishers, 2013), 392, 411. Muhammad S. al-'Ashmawi, al-Shari'a al-Islamiyya wa al-Qanun al-Masri (1996), 10. 


\subsection{Incompatibility}

Finally, devout Muslims may concede defeat and acknowledge that certain rules of Islam cannot be applied or observed even if they believe that they should. Rules on gender segregation, for example, cannot be implemented or accommodated by a Western state. Muslims may, however, live in accordance with these rules within the smaller circles of their families or communities, not unlike some orthodox Jewish and Christian communities in the West do.

\section{$3 \quad$ Strategies}

The different ways in which the rules of Islam are being practiced in a setting that we have called "informal legal practices," that is, without any enforcement other than from within the individual or community, imply that they form an intrinsic part of the social dynamics and strategies of Muslim communities. Filing a case against one's husband before a British Sharia council may have no formal legal effect, but the shaming and blaming within the community can produce better results than any court of law. ${ }^{89}$ Similarly, Muslim girls may circumvent their parents' choice of spouse by presenting them with an Islamic marriage with a partner of the girl's own choice. ${ }^{90}$

Similar strategies are used when involving the formal legal structure outside the Muslim community. For some Muslims, this may be to assert their identity as a strategy for the "accommodation of difference" (the many headscarf cases raised by Muslims before the courts across Europe are a case in point). ${ }^{91}$ But such strategies can also be used for opposite ends: litigation before a civil court is being used, mostly by women, to right the wrongs of religious law. A woman whose 'husband' in an informal religious marriage refuses to pay the mandatory dower (mahr), can claim this dower through a civil court by considering this dower civil part of an agreement, and as such as a matter of civil contract law. ${ }^{92}$ And the Muslim woman who is religiously married may try to persuade the civil court that her husband is committing an act of tort by refusing to

\footnotetext{
89 Samia Bano, "Muslim Family Justice and Human Rights: The Experience of British Muslim Women", 2 Journal of Comparative Law (2007), 38; Shah-Kazemi, supra note 8.

9o Moors, supra note 7.

91 Malik, supra note 34, at 113.

92 See literature, supra note 27.
} 
grant her an Islamic divorce by means of talaq (a similar predicament is also known to women maried under Jewish law $\left.{ }^{93}\right) \cdot{ }^{94}$

Research on the extent and nature of these strategies is limited, but it appears that these uses and abuses by individual Muslims of both rules of Islam and Western political and legal infrastructures are not incidental. Further research in this domain is welcome, because it would give a more accurate and rounded picture of the nature of Sharia in the West, and in particular of the dialectic with its Western environment.

\section{Concluding Remarks}

The main challenge of understanding Sharia in the West is its undefined nature. This is contrary to the ease with which this term is used in public and political discourse, but also in the legal field, which in the West has always prided itself for its precise terminology. The model presented in this article provides an analytical tool that gives us answers to and insights in the questions: What is the Sharia that these Muslims in the West want and practice, and to what extent are they allowed to practice it?

From a Western perspective, these answers and insights are both worrisome and reassuring. The worry has to do with the fact that an increasing number of Muslims in the West wish to live in accordance with the rules of Islam, and that the current examples of such rules inside and outside the West are quite alarming: harsh forms of Sharia are being implemented by Muslim countries and organizations worldwide, and terrorist attacks are being committed by Muslims who invoke Sharia to justify their actions. The reassurance provided by this model, however, lies in the forms of Sharia practiced by the majority of Muslims in the West, which is limited to three domains: religious ritual, family and finance law, and interaction

93 Michael J. Broyde, Marriage, Divorce, and the Abandoned Wife in Jewish Law: A Conceptual Understanding of the Agunah Problems in America (KTAV Publishing House Inc., 2001); Jill Wexler, "Gotta Get a Get: Maryland and Florida Should Adopt Get Statutes" Journal of Law and Policy (2009), 735 .

94 In the Netherlands, courts have shown willingness to interfere, not on the basis of religious law, but because the unwillingness of the man to religiously divorce his wife is considered a matter of tort if they already live as a divorced couple; Maurits S. Berger, "Het afdwingen van een islamitische verstoting", 2 Tijdschrift voor Religie, Recht en Beleid (2011), 99. In the UK, this problem has received longstanding legislative and political attention and has been resolved by the Divorce (Religious Marriages) Act 2002; Lucy Caroll, "Muslim women and 'Islamic divorce' in England", 17 Journal of Muslim Minority Affairs (1997), 97. 
with the non-Muslim environment. The practice of Sharia in the West, therefore, is mostly of a private nature and only occasionally clashes with its not-soreligious environment. In this respect, there is little difference between Islam and other religious communities in the West.

Examining the mechanisms of Sharia in the West demands a reassessment of terminology. For a number of reasons, I have proposed to substitute the term "Sharia" with "rules of Islam." In the case of the West, these rules are not a static code, but a set of rules practiced by Muslims in an autonomous manner, engaged in a continuous interaction with the West. We have defined the West as a system that is dominant, not only legally, but also politically, socially, and culturally. From this dominant position the West produces two responses: political-legal and cultural-religious. The model shows that many rules of Islam as practiced by Muslims in the West do not contradict laws, constitutions, or political values such as freedom or equality. The political-legal response, therefore, is mostly accommodating towards rules of Islam. Most of the negative reactions to rules of Islam come from the cultural-religious response, defined as the gut feeling of "this is not how we do things here." This response has become dominant to the extent that it often overrides politicallegal considerations.

The ongoing dialectic between rules of Islam and the West encourages both sides to re-evaluate what rules can be considered essential, to develop strategies to uphold these rules, and find solutions in cases they conflict with each other. The model enables us to study a process that is more dynamic than one would initially assume, and which confronts both sides with fundamental questions about their legal and religious values, and about the role of religion in Western legal systems.

In this ongoing dialectic, I observe several worrisome developments of which I will mention two. With regard to the Muslim Westerners, the increase in their religiosity is accompanied by an intense focus on the rules of religion. This trend of what I call "legalisation of religion" removes the Muslims from the spiritual dimensions of Islam, and reduces their life in the West to the rigidity of haram-halal (forbidden-allowed). In the case of non-Muslim Westerners, on the other hand, I am concerned about the manner how cultural-religious values are presented, framed, or experienced as being under threat and in need of protection. Legislation is increasingly being used to achieve this protection, banning practices that political-legal values otherwise allow. Although in some instances measures may indeed be justifiable for reasons of state security, I argue that by taking this course the West is not so much challenged by Islam, but by its own values: is the West willing to live up to its core political-legal values as enshrined in constitutions and international treaties, or does it want to uphold and even enforce religious-cultural particularism? 